\title{
Human Impacts on Fluxes of Nutrients and Sediment in Waimānalo Stream, O'ahu, Hawaiian Islands ${ }^{1}$
}

\author{
Edward A. Laws ${ }^{2}$ and Lisa Ferentinos ${ }^{3}$
}

\begin{abstract}
Waimannalo Stream, on the windward side of the island of O'ahu in the Hawaiian Islands, has been greatly altered by human activities. Native riparian vegetation has been removed along much of the course of the stream, and significant sections of the stream have been hardened to control flooding. Absence of shade from riparian vegetation has allowed California grass (Brachia mutica), wild sugarcane (Saccharum officinarum), and other vegetation to proliferate in the stream channel. Some reaches of the stream more closely resemble a wetland than a natural watercourse. During fair weather and moderate storms, this vegetation effectively traps sediment. During a year when rainfall was $\sim 40 \%$ below average, dissolved $\mathrm{N}$ and $\mathrm{P}$ accounted for most of the $\mathrm{N}$ and $\mathrm{P}$ transported by the stream. $\mathrm{N}$ and $\mathrm{P}$ content of the suspended solids was comparable with that of terrestrial organic matter, but with a slightly lower N/P ratio, probably due to the high iron content of Hawaiian soils. Concentration of suspended solids in the stream was only about $4 \%$ of the average concentration in fluvial systems that discharge to the ocean. Base flow accounted for about $32 \%$ of the $\mathrm{P}, 58 \%$ of the suspended solids, and $96 \%$ of the $\mathrm{N}$ transported by the stream. The very high contribution of base flow to the $\mathrm{N}$ flux was apparently related to contamination of shallow groundwater in the lower reach of one tributary, in which nitrate $\mathrm{N}$ concentrations during base flow were about $7 \mathrm{mg}$ liter $^{-1}$. Flux of $\mathrm{N}$ in the stream was comparable with the amount of $\mathrm{N}$ produced by livestock waste in this predominantly agricultural watershed. Cesspool seepage and/or leaching of $\mathrm{N}$ from animal waste into shallow groundwater and seepage of that groundwater into the stream may account for the anomalously high $\mathrm{N}$ loading to the stream. Absence of a similarly high $\mathrm{P}$ flux probably reflects the high iron content of Hawaiian soils, which effectively immobilize $\mathrm{P}$ in groundwater.
\end{abstract}

THE IMPACT OF human activities on sustainable ecosystem functionality in the coastal zone has become a matter of considerable

\footnotetext{
${ }^{1}$ Supported in part by a Hawai'i Coral Reef Initiative program grant. School of Ocean and Earth Science and Technology contrib. no. 5989. Manuscript accepted 13 May 2002.

2 Department of Oceanography and Hawai' $\mathrm{i}$ Institute of Marine Biology, School of Ocean and Earth Science and Technology, University of Hawai'i at Mānoa, Honolulu, Hawai'i 96822.

${ }^{3}$ Waimānalo Watershed Project, 41-1537 Kalaniana'ole Highway, Box 4, Waimānalo, Hawai'i 96795.
}

Pacific Science (2003), vol. 57, no. 2:119-140

(C) 2003 by University of Hawai' $i$ Press

All rights reserved environmental concern. Weber (1993:19), for example, pointed out, "Nutrients and sediments have become pollutants that degrade estuaries and coastal waters by prompting algal blooms, blocking sunlight, suffocating fish and coastal habitats, and carrying pathogens and toxins. Globally, nutrient and sediment pollution have contributed to the decline of estuaries, coastal wetlands, coral reefs, seagrass beds, and other coastal ecosystems." Peierls et al. (1991:387) noted that there is a remarkably good correlation between human population density and nitrate concentrations in river water and concluded, "Human activity clearly dominates nitrate export from land." During the last $40 \mathrm{yr}$ nearly one-third of the world's arable land has been lost by erosion and continues to be 
lost at a rate of more than 10 million ha per year (Pimentel et al. 1995). World fertilizer consumption increased by an average of 4.4 million tonnes per year from 1960 to 1990 (Ver et al. 1994) and is expected to increase at a rate of $2.2 \%$ per year for the next $5 \mathrm{yr}$ (IFC 2001). These trends in erosion and fertilizer use are driven largely by the size of the human population, which currently numbers about 6.2 billion.

Although patterns of soil erosion and fertilizer use account for a substantial percentage of the increase in sediment and nutrient delivery to aquatic ecosystems, an important component of the nutrient and sediment problem is associated with the destruction of buffer zones that would normally serve to minimize impacts of land runoff. Among the most important such buffer zones are estuaries and marshes in the coastal zone and the riparian habitat along streams. In its discussion of sediment source controls, for example, the U.S. Environmental Protection Agency commented, "In some cases, it is possible to reduce or prevent delivery of eroded sediments to streams by developing or maintaining buffer strips, vegetated swales, or sediment detention basins, some of which also provide collateral benefits in the form of wildlife habitat, nutrient trapping, and stream shading" (U.S. Environmental Protection Agency 1999a:2-2). Following up on this line of reasoning, the Chesapeake Bay Program is attempting to restore $3200 \mathrm{~km}$ of streambank and shoreline riparian forest buffers in the Chesapeake Bay watershed by the year 2010 (Chesapeake Bay Program 1999).

In many cases coastal habitats have also been modified by the diversion of freshwater for irrigation, the hardening of stream channels for flood control, or the damming of streams to better regulate public water supplies, control flooding, produce hydroelectric power, or provide recreational habitat. In commenting on the relationship between water quality and flow, the U.S. Environmental Protection Agency has pointed out, "Some impairments are aggravated (or caused primarily) by flow modifications that result from in-stream diversions or catchments.... It is important to identify the flow regimes necessary to satisfy designated uses and to identify situations where flow modifications might make use attainment difficult or impossible" (U.S. Environmental Protection Agency 1999b:2-5). Although too much sediment can cause serious water quality problems, "Erosion is a natural process and some sedimentation is needed to maintain healthy stream systems.... In some waters, hydrologic modifications (e.g., dams) can cause sediment deficits that result in stream channel scour and destruction of habitat structure" (U.S. Environmental Protection Agency 1999a:2-1).

Relevant to the link between habitat sustainability and the size of the human population is the fact that during the first quarter of the twenty-first century much of the world's human population growth will occur in underdeveloped countries located in the Tropics or subtropics. During that time the human population is expected to increase from its current level to almost 8.1 billion, an increase of 1.9 billion persons (Population Reference Bureau 1999). The 10 nations projected to experience the greatest population increase will account for about $60 \%$ of that figure, or 1.1 billion. Only three of those nations (China, Pakistan, and the United States) lie wholly or largely outside the subtropics. The remaining 7 (Bangladesh, Brazil, India, Indonesia, Mexico, Nigeria, and Zaire) lie entirely or largely within the Tropics, and their population increase is expected to amount to 727 million, $64 \%$ of the increase accounted for by the top 10 nations. It seems reasonable to conclude that during the next 25 yr more than half the world's human population increase will occur within the Tropics and subtropics.

Because of the anticipated growth of the human population, there is an urgent need to understand present anthropogenic impacts on the global ecosystem and to predict and help to mitigate future adverse effects. About 2.5 billion people or $40 \%$ of the human population resides within $100 \mathrm{~km}$ of the world's coastal margins (Miller 1999) and more than half the population increase in the next $25 \mathrm{yr}$ is expected to occur in the Tropics and subtropics, so it seems clear that a good under- 


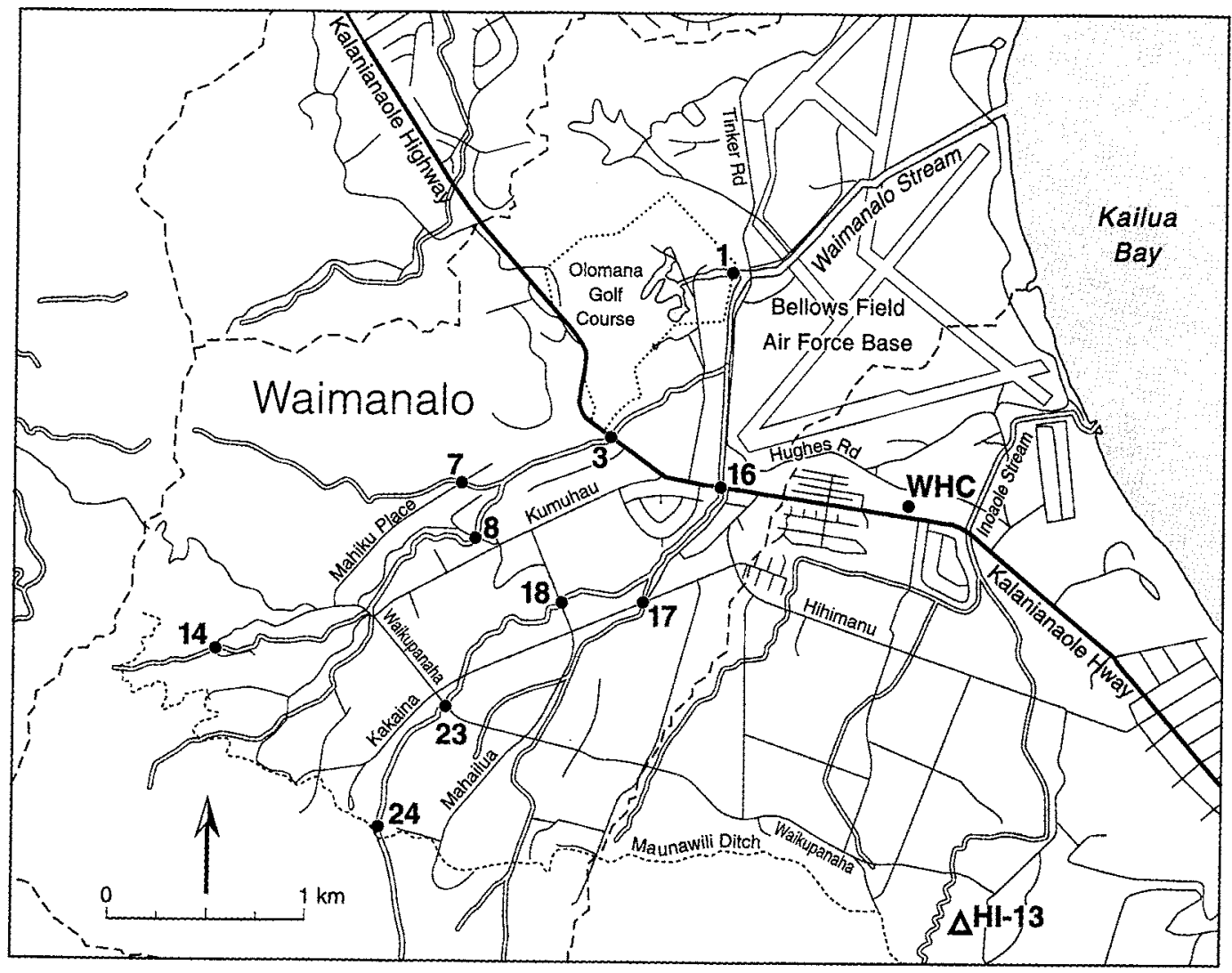

Figure 1. Waimānalo Stream watershed and location of sampling stations. Dashed line indicates boundaries of the watershed.

standing of natural and disturbed ecosystems in tropical and subtropical latitudes is needed and that particular attention should be devoted to the land-coastal margin.

The work described here focused on the impact of land use and stream habitat modification on the transport of nutrients and sediment in a $15.3-\mathrm{km}^{2}$ watershed on the windward side of the island of $\mathrm{O}^{6} \mathrm{ahu}$ in the Hawaiian Islands (Figure 1). The watershed is drained by Waimānalo Stream, which originates on the eastern side of the Ko'olau Mountains. The stream consists of two principal tributaries, Waimānalo Stream to the north and Kahawai Stream to the south. The two streams merge roughly $0.5 \mathrm{~km}$ below Kalaniana'ole Highway (Figure 1). The stream enters the ocean at Bellows Beach about $2 \mathrm{~km}$ below the confluence of the two tributaries. The distance from the headwaters to the mouth of the stream is approximately $5.5 \mathrm{~km}$.

\section{Land Use}

Before European contact more than 800 taro lo'i (pond fields) lined upper and middle Waimānalo Stream and its tributaries. Banks were covered with mostly low-growing and shrubby cultivated plants. The middle elevations were filled with sweet potato (Ipomoea batatas), breadfruit (Artocarpus altilis), and mountain apple trees (Eugenia malaccensis). Land Court award documents indicate that the lower wetland areas included inland fishponds and a few lo'i (Sustainable Resources 
Group International 2001). The impacts of Western disease and the change in land tenure ended traditional farming, which was replaced by livestock ranching. From the late nineteenth to the mid-twentieth centuries a series of water diversions, including dams in the stream and a network of irrigation ditches, made sugarcane cultivation possible. When sugarcane cultivation ended in the mid-1940s, the land was broken up into nurseries and livestock and truck farms (Bartholomew and Associates 1959). Increasing urbanization along the highway resulted in channelization of portions of the streams in the 1960 s to avert flooding of the small subdivision lots. Development of runways on the military base and the construction of the Olomana Golf Course (Figure 1) drained the lower wetland areas, changed the course of the stream, and eliminated the lagoon that previously existed at the mouth of the stream (Sustainable Resources Group International 2001).

Recent land use in the watershed has been the subject of a study by the Hawai' $i$ Department of Health (1998) and Kihara (2001). Based on zoning maps, Kihara estimated the land to be about $3 \%$ urban, $48 \%$ conservation or steeply sloping, and $49 \%$ agricultural. The higher-elevation portions of the watershed are entirely in the conservation/steeply sloping category, where the slopes of the fluted cliffs (pali) range from $45^{\circ}$ to nearly $85^{\circ}$ and are steepest between altitudes of 200 and $450 \mathrm{~m}$. A talus slope generally obscures the lower parts of the cliffs below an altitude of $200 \mathrm{~m}$ (Takasaki et al. 1969). The City and County of Honolulu zoning classifications designate land use in the watershed as $54 \%$ preservation, $41 \%$ agriculture, $3 \%$ country, and $2 \%$ residential (Hawai $i$ Department of Health 1998). The preservation category includes both conservation and military lands. The latter includes Bellows Field Air Force Base, which, together with the Olomana Golf Course, accounts for all the lowest-elevation land in the watershed (Figure 1). The mountainous preservation land is largely undeveloped. During the era of sugarcane cultivation in the watershed, a water diversion system known as the Maunawili Ditch was used to intercept stream runoff within the preservation land and route that runoff to sugarcane fields. Its use for that purpose ceased during the mid-1940s. From that time until 1955 the Maunawili Ditch was used to provide irrigation water for diversified agriculture. The ditch ceased to play a role in agriculture in 1955. At the current time runoff intercepted by the ditch is transported to the nearest stream. About $2.4 \mathrm{~km}^{2}$ of Bellows land is used for military training exercises, and there is some helicopter training on part of an abandoned runway. There is a beach park along the seashore and some recreational cabins and campgrounds. Sanitary facilities for the cabins and campgrounds are serviced by cesspools, which may allow seepage into the nearshore ocean but have no potential to impact Waimānalo Stream.

The human impact on land use has been primarily on the agricultural land. About $47 \%$ of the agricultural land is used for grazing livestock (Table 1). The livestock population has been estimated to include 321 horses, 550 hogs, 62 cattle, and 2803 chickens (Medeiros 1998). Using typical animal excretion rates (Medeiros 1998), these animals are estimated to produce about 29 tonnes of nitrogen and 7 tonnes of phosphorus per year. Ninety percent of the hog population is located at a single facility on Waikupanaha Street between Kaka'ina and Kumuhau Streets (Figure 1). The remaining population of livestock is

\section{TABLE 1}

Percentage of Agricultural Land Devoted to Specified Activities (Hawai'i Department of Agriculture 1987)

\begin{tabular}{lc}
\hline Agricultural Activity & $\begin{array}{c}\text { Percentage of Agricultural } \\
\text { Land in Watershed }\end{array}$ \\
\hline Grazing & 47.0 \\
Banana & 19.7 \\
Foliage and nursery & 15.1 \\
Flowers & 9.1 \\
Dairy & 5.7 \\
Vegetables & 0.5 \\
Poultry & 0.4 \\
Orchards & 0.4 \\
Field crops & 0.3 \\
Unspecified & 1.8 \\
\hline
\end{tabular}




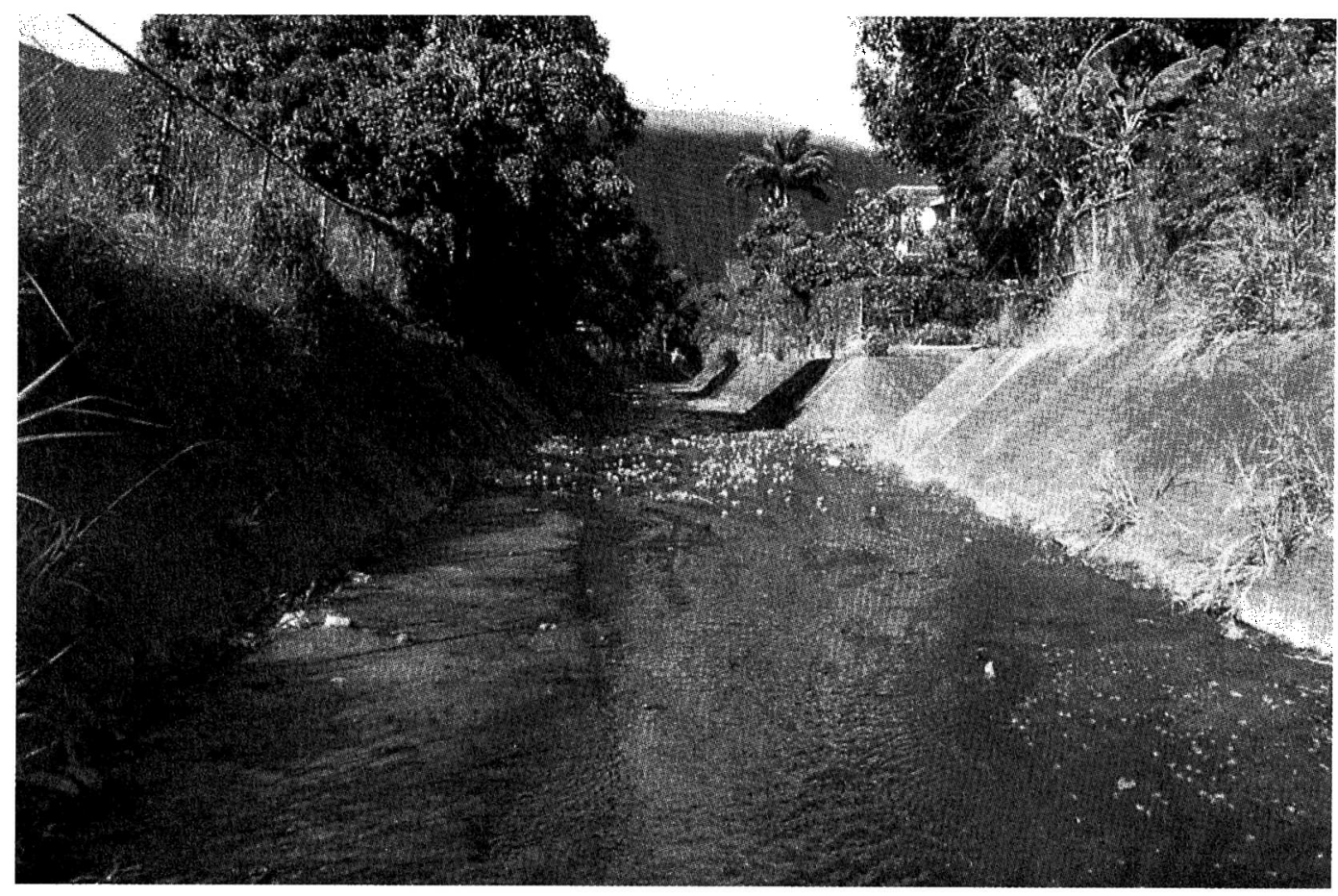

FIGURE 2. Hardened portion of Kahawai Stream just above station 16 (Figure 1).

scattered widely throughout the watershed between Kalaniana'ole Highway and the Ko'olau Mountains (Medeiros 1998). The experimental design therefore focused on fluxes from the watershed above Kalaniana'ole Highway. Storm events could leach nutrients from accumulated animal waste into groundwater and/or transport the waste into drainage ways and streams (Hawai'i Department of Health 1998). Fertilizers applied to agricultural crops are another potential source of nutrient loading. A large number of nurseries, for example, are located adjacent to perennial streams or intermittent drainage ways in the watershed (Hawai'i Department of Health 1998). However, Medeiros (1998:7) pointed out that, "Nurseries use the manure as fertilizer for their crops." In other words, fertilizer and manure are to a large extent synonymous in Waimānalo, and estimates of nutrient loading associated with animal waste production implicitly include most fertilizer use.

\section{Stream Habitat Modification}

Waimānalo Stream is a highly altered waterway that in many respects no longer functions as a stream (Harrigan and Burr 2001). Stream channels have been heavily modified over the last hundred years by a variety of agricultural and flood control projects. Stream hardening, channelization, and the removal of riparian vegetation have transformed some reaches of the stream into a waterway that closely resembles a storm sewer (Figure 2). The elimination or reduction of shade provided by riparian vegetation has encouraged the growth of channel-clogging California grass, wild sugarcane, and other vegetation that take up water and trap sediments (Figure 3). Dams and irrigation ditches have dramatically altered the natural flow of water in the stream. The result is that portions of Waimannalo Stream are now stagnant wetlands rather than free-flowing waters. As noted by Harrigan and Burr (2001:14), "Regardless of how many 


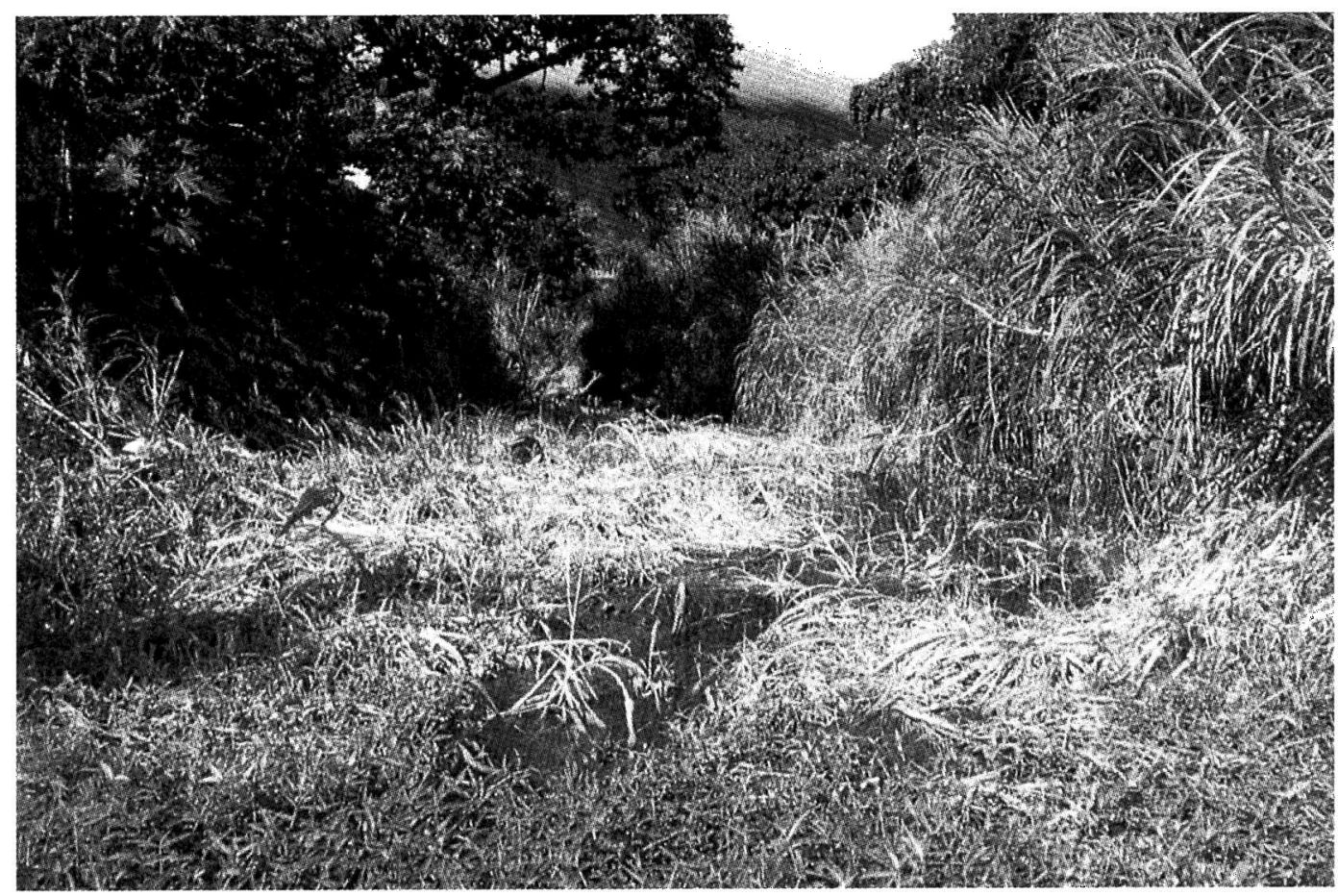

Figure 3. Portion of Kahawai Stream clogged with California grass and wild sugarcane. The location is just below station 17 (Figure 1).

BMPs [best management practices] are implemented for sediment and nutrient control, significant improvement in the water quality of Waimānalo Stream will be difficult to achieve unless in-stream standards for flows are set to increase the base flow and stream channels and riparian wetlands are at least partly restored to their natural form and function."

\section{MATERIALS AND METHODS}

Fluxes of sediment and nutrients (nitrogen, phosphorus, and silicate) were estimated at a series of 10 locations in the watershed from March 1999 to April 2000. Five of the stations were located on the Kahawai tributary, and four were located on the Waimanalo Stream tributary (Figure 1). The tenth station (station 1) was located on a small tributary below the confluence of Waimanalo and $\mathrm{Ka}$ hawai Streams, where runoff from the Olo- mana Golf Course enters the stream. With the exception of stations 14 and 24, all stations were located at road crossings to facilitate estimation of discharges from flow rate and channel geometry beneath the bridges. The work focused on runoff during storms. Samples were collected on at least three occasions for each storm. Additional samples were collected during base flow conditions (dry weather) for comparative purposes. Information from the base flow sampling was augmented by base flow monitoring data collected by the Hawai'i Department of Health at stations 16, 18, and 23.

Estimates of discharges were usually made by estimating the flow rate and multiplying the flow rate by the cross-sectional area of the channel. In some cases discharges were determined from the time needed to fill a 10.4liter bucket at a convenient waterfall (stations 14 and 18). The more common method of discharge estimation was to drop a buoyant 
object into the water on the upstream side of a culvert and record the time for the object to appear on the downstream side (U.S. Geological Survey 1982). A coefficient of 0.85 was used to convert the flow rate estimated from the velocity of a surface float to the mean velocity in the vertical (U.S. Geological Survey 1982:262).

Teams of at least two persons collected water samples. Each team was assigned three or four stations to monitor during a storm. The protocol was to sample each station at least three times during each storm. Additional samples were collected at stations 3 and 16 (Figure 4). Water samples were collected with a plastic 10.4-liter bucket, either by lowering the bucket into the water from a culvert or by wading into the stream. In the latter case the sample was always collected upstream of the person taking the sample. Each sample was dispensed into a 1-liter selfsealing plastic (Ziploc) bag and a 250-ml plastic sample bottle. The bag samples were double-bagged to guard against leakage and contamination and placed in a cooler containing either ice or ice substitute (Blue-ice) packs. The samples in the plastic bottles were maintained at ambient temperature.

Flow rate measurements were made immediately after collecting the water sample. The time required for a buoyant object to pass from the upstream to the downstream

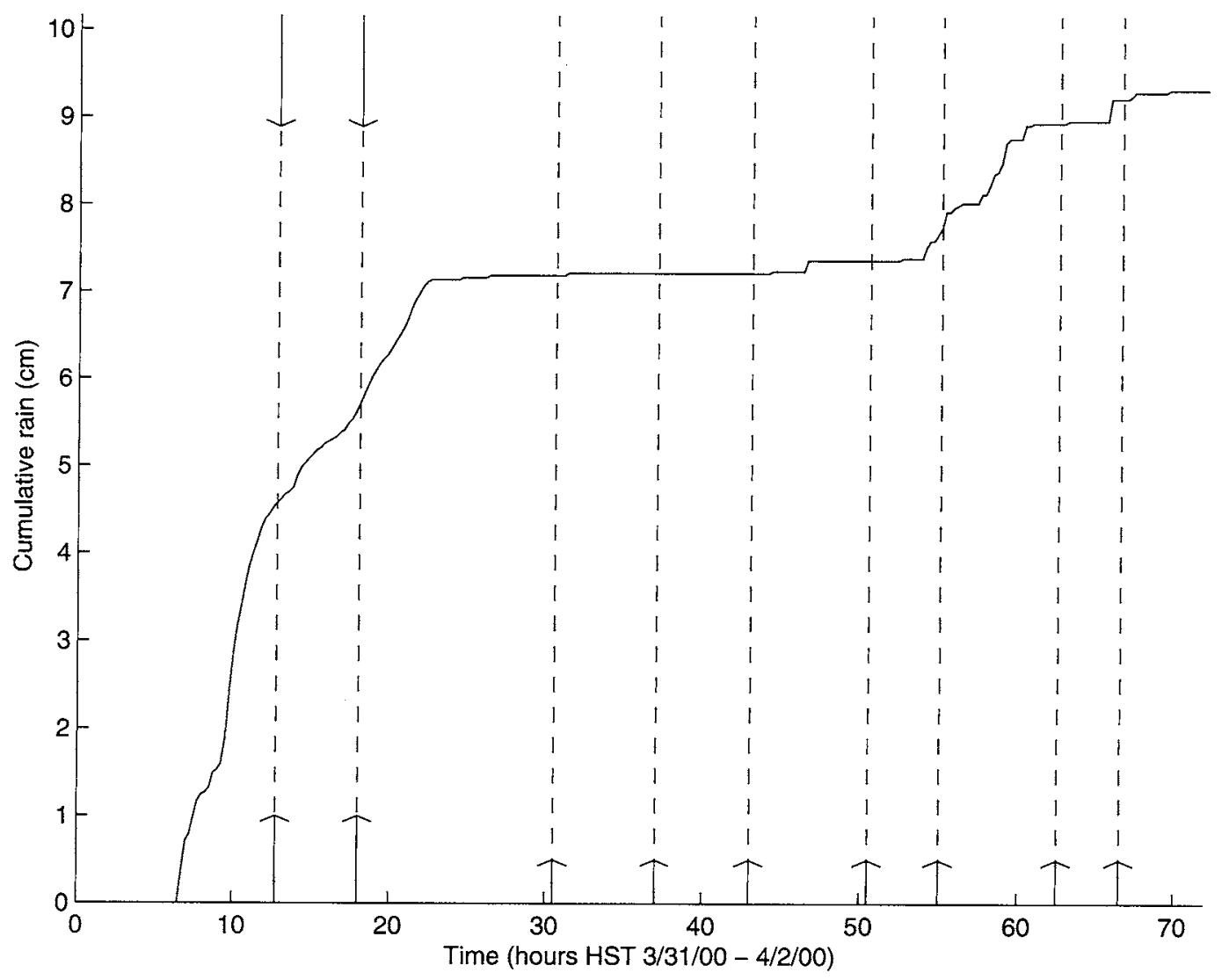

FIGURE 4. Time series of cumulative rainfall in Waimānalo during the period 31 March 2000 through 2 April 2000. Double arrows and dashed lines indicate the time intervals during which samples were taken at all sampling stations. Smaller single arrows and dashed lines indicate discrete times at which samples were collected for turbidity, suspended solids, and nutrients from stations 3 and 16 . 
side of a culvert was recorded to the nearest $0.1 \mathrm{sec}$ with a stopwatch. Alternatively, the time required for the water to fill a 10.4-liter bucket was recorded to the nearest $0.1 \mathrm{sec}$. The flow rate measurements were repeated three times. Finally the depth of the water was recorded at the center of the stream channel. In the case of wide channels (e.g., $15 \mathrm{~m}$ at station 3), depths were noted at both the center and the sides of the channel.

The Waimānalo Health Center (WHC, Figure 1) was used as the base of operations during every storm. After each round of sampling, a team returned to the WHC to measure the turbidity of the samples in the plastic bottles and to store the plastic bag samples in an ice chest. Analytical methods adhered to those described in American Public Health Association (1998). Turbidities were measured using a turbidity meter (Hach model 2100P) and recorded in nephelometric turbidity units (NTUs). These readings usually were made and recorded three times. The measurements proved to be highly reproducible.

After sampling on a given day had been completed, the samples in the ice chests were taken to the University of Hawai'i Oceanography Department for further processing. Aliquots of usually $250 \mathrm{ml}$ were filtered through preweighed glass fiber filters (Whatman GFF) with a nominal porosity of $0.7 \mu \mathrm{m}$. The filters were dried in a drying oven at $105^{\circ} \mathrm{C}$ to constant weight. The filters were weighed on an analytical balance (Mettler model H20T) to the nearest $0.01 \mathrm{mg}$. Duplicates were run on random samples as a check on precision. Blanks were run by filtering $250 \mathrm{ml}$ of distilled water through a filter. The weight of material collected on the filters ranged from a few milligrams to several tens of milligrams. The blank correction was less than $0.1 \mathrm{mg}$. The concentration of suspended solids was calculated from the difference in the weights of the filter before and after filtering.

The filtrate from the suspended solids (SS) filtration step was transferred to plastic (whirl-pak) bags and processed for nutrient concentration measurements. The filtrates were frozen if not immediately analyzed.
Concentrations of nitrate + nitrite (hereafter nitrate), phosphate, silicate, and ammonium + ammonia (hereafter ammonium) were measured on the filtrate using colorimetric techniques on a spectrophotometer (Varian model DMS 100). The procedures used for the colorimetric assays adhered to those described in American Public Health Association (1998). Concentrations of total dissolved nitrogen (TDN) and total dissolved phosphorus (TDP) were determined by first oxidizing the organic matter in the filtrates with an ultraviolet light photooxidation unit (Ace-Hanovia). Dissolved inorganic nitrogen (DIN) was equated to the sum of nitrate and ammonium. Dissolved organic nitrogen (DON) and dissolved organic phosphorus (DOP) were equated to the difference between TDN and DIN and between TDP and phosphate, respectively. Particulate nitrogen (PN) and particulate phosphorus (PP) were determined by placing the filters used for the $\mathrm{SS}$ analyses in $100 \mathrm{ml}$ of distilled deionized water and oxidizing them in the same manner as in the TDN and TDP assays. Total nitrogen (TN) and total phosphorus (TP) were equated to the sum of TDN and PN and the sum of TDP and PP, respectively.

Base flow samples were collected on 26 March 1999 and 10 April 1999. These results were augmented by base flow monitoring data (turbidity, nutrients, SS) collected at stations 16,18 , and 23 by the Hawai' $i$ Department of Health on a total of 19 occasions between 24 November 1998 and 15 November 1999. Four storm events were sampled (16 May 1999, 22-23 December 1999, 19-20 January 2000, and 31 March-2 April 2000). During each of the four storm events, there were two peaks in rainfall separated by a welldefined period of no rain. In the case of the 16 May 1999 event, no samples were collected during the first rainfall peak. In the other cases samples were collected during or immediately after the rain events.

\section{RESULTS}

Cumulative rainfall for the storms of 16 May 1999, 22-23 December 1999, 19-20 January 2000, and 31 March-2 April 2000 was 5.6, 
$4.2,3.6$, and $9.3 \mathrm{~cm}$, respectively. Figure 4 shows the time series of cumulative rainfall for the largest storm (31 March-2 April 2000) and the time intervals during which samples were collected. Rainfall data were obtained from the National Weather Service (NWS) Waimānalo Hydronet station HI-13 located at $21^{\circ} 20^{\prime} \mathrm{N}, 157^{\circ} 43^{\prime} \mathrm{W}$ (Figure 1).

Only about $2.5 \mathrm{~cm}$ of rain fell during the 45 days before 16 May 1999. The ground was therefore very dry before the 16 May 1999 storm. There were no significant storms during the months of June through November 1999 , but there were several good rains during December 1999. Cumulative rainfall for that month was $18.7 \mathrm{~cm}$. The storm of $22-23$ December 1999 contributed about 22\% of that amount. Cumulative rainfall during January 2000 was only $6.3 \mathrm{~cm}$, and the storm we sampled accounted for $57 \%$ of that total. Rainfall in February 2000 totaled only 0.74 $\mathrm{cm}$. Cumulative rainfall for the months of March and April 2000 was $13.11 \mathrm{~cm}$. The storm we sampled accounted for $71 \%$ of that total.

Table 2 summarizes the average concentrations of nutrients and SS at stations 3 and 16 during wet and dry weather. The wet weather conditions have been divided into periods when rain was falling and when rain had ceased falling but runoff from the storm was still in progress. Nitrate accounted for most of the TN (58-90\%) at all times. Phosphate accounted for most of the TP when rain was in progress $(61-72 \%)$, but the contribution of phosphate to TP declined during the postrain period (45-52\%), and phosphate accounted for only about one-third of the TP during base flow. SS concentrations were elevated by a factor of 5-17 when rain was in progress versus base flow. Postrain SS concentrations were about half the concentrations measured when rain was in progress. Silicate concentrations were 5-10 times higher during wet weather versus base flow.

Table 3 compares the median nutrient and SS fluxes at upstream stations with the corresponding concentrations at stations 3 and 16 during wet weather. The flow of water at station 7 was either zero or very small on all occasions. Any flow that was observed at sta-
TABLE 2

Average Concentrations (mg liter ${ }^{-1}$ ) of Nutrients and SS at Stations 3 and 16

\begin{tabular}{|c|c|c|c|}
\hline $\begin{array}{l}\text { Station No./Nutrients } \\
\text { and SS }\end{array}$ & $\begin{array}{c}\text { During } \\
\text { Rain }\end{array}$ & Postrain & $\begin{array}{l}\text { Base } \\
\text { Flow }\end{array}$ \\
\hline 16 (Kahawai tributary) & $n=10$ & $n=12$ & $n=21$ \\
\hline Ammonium $\mathrm{N}$ & 0.14 & 0.06 & 0.03 \\
\hline Particulate N & 0.09 & 0.14 & 0.03 \\
\hline Nitrate $N$ & 2.59 & 4.27 & 7.1 \\
\hline DON & 0.64 & 0.27 & \\
\hline Total N & 3.46 & 4.73 & 6.8 \\
\hline Phosphate P & 0.192 & 0.11 & 0.01 \\
\hline Particulate P & 0.0 & 0.05 & 0.01 \\
\hline DOP & 0.021 & 0.05 & 0.01 \\
\hline Total P & 0.265 & 0.21 & 0.03 \\
\hline Silicate Si & 8.1 & 10.0 & 2.0 \\
\hline SS & 80 & 44 & 16 \\
\hline 3 (Waimānalo tributary) & $n=10$ & $n=12$ & $n=2$ \\
\hline Ammonium $N$ & 0.06 & 0.04 & 0.03 \\
\hline Particulate $N$ & 0.13 & 0.11 & 0.02 \\
\hline Nitrate $\mathrm{N}$ & 0.99 & 1.07 & 0.38 \\
\hline DON & 0.19 & 0.25 & 0.22 \\
\hline Total N & 1.37 & 1.47 & 0.66 \\
\hline Phosphate P & 0.107 & 0.054 & 0.01 \\
\hline Particulate $\mathbf{P}$ & 0.038 & 0.031 & 0.006 \\
\hline DOP & 0.029 & 0.035 & 0.016 \\
\hline Total P & 0.174 & 0.121 & 0.031 \\
\hline Silicate Si & 8.9 & 9.9 & 1.1 \\
\hline SS & 75 & 32 & 4.4 \\
\hline
\end{tabular}

Note: Values from rain and postrain periods are flowweighted averages. $n=$ number of samples.

tion 7 came from a drainage ditch that intercepted runoff from Mahikū Place. Runoff from the Olomana Golf Course was also negligible compared with the fluxes at other stations. The system of water hazards at the golf course appears to function as a rather effective detention basin. The flux of water from the golf course into Waimānalo Stream may occur primarily via lateral movement of groundwater. Roughly $65-77 \%$ of the water, nutrient, and SS flux at station 3 (Waimānalo Stream) occurred in the upper portion of the watershed and was accounted for at station 8 . At station 16 (Kahawai Stream), on the other hand, $70-86 \%$ of the corresponding fluxes occurred in the lower portion of the watershed below stations 17 and 18 .

Figure 5 shows the relationship between turbidity and suspended solids based on the data collected at all stations. The correlation coefficient between turbidity and suspended 
TABLE 3

Median Percentage Fluxes of Water, Nutrients, and SS at Indicated Stations Relative to Lowest-Elevation Stations in Waimānalo Stream (Station 3) and Kahawai Stream (Station 16) Based on 18 Paired Samples Collected during Rain and Postrain Conditions (Error Bounds Are $95 \%$ Confidence Intervals)

\begin{tabular}{lccccc}
\hline \hline Stream & Water Discharge & Nitrate N Flux & TN Flux & TP Flux & SS Flux \\
\hline Waimānalo & & & & & \\
Station 8 & $70(40-143)$ & $65(28-109)$ & $67(28-138)$ & $74(32-95)$ & $77(26-110)$ \\
Station 14 & $16(11-28)$ & $2(0.3-15)$ & $5(2-8)$ & $11(6-27)$ & $11(7-38)$ \\
Kahawai & & & & & \\
Station 17 & $1.5(0-5)$ & $2(0-17)$ & $1.5(0-8)$ & $4(0-10)$ & $0.5(0-3)$ \\
Station 18 & $26(20-71)$ & $7(4-14)$ & $9(6-20)$ & $20(9-41)$ & $24(17-34)$ \\
Station 23 & $19(8-30)$ & $2(0.4-3)$ & $3(1-5)$ & $8(2-14)$ & $7(5-19)$ \\
Station 24 & $6(0-20)$ & $0.1(0-0.4)$ & $0.3(0-1)$ & $1(0-5)$ & $0.3(0-8)$ \\
\hline
\end{tabular}

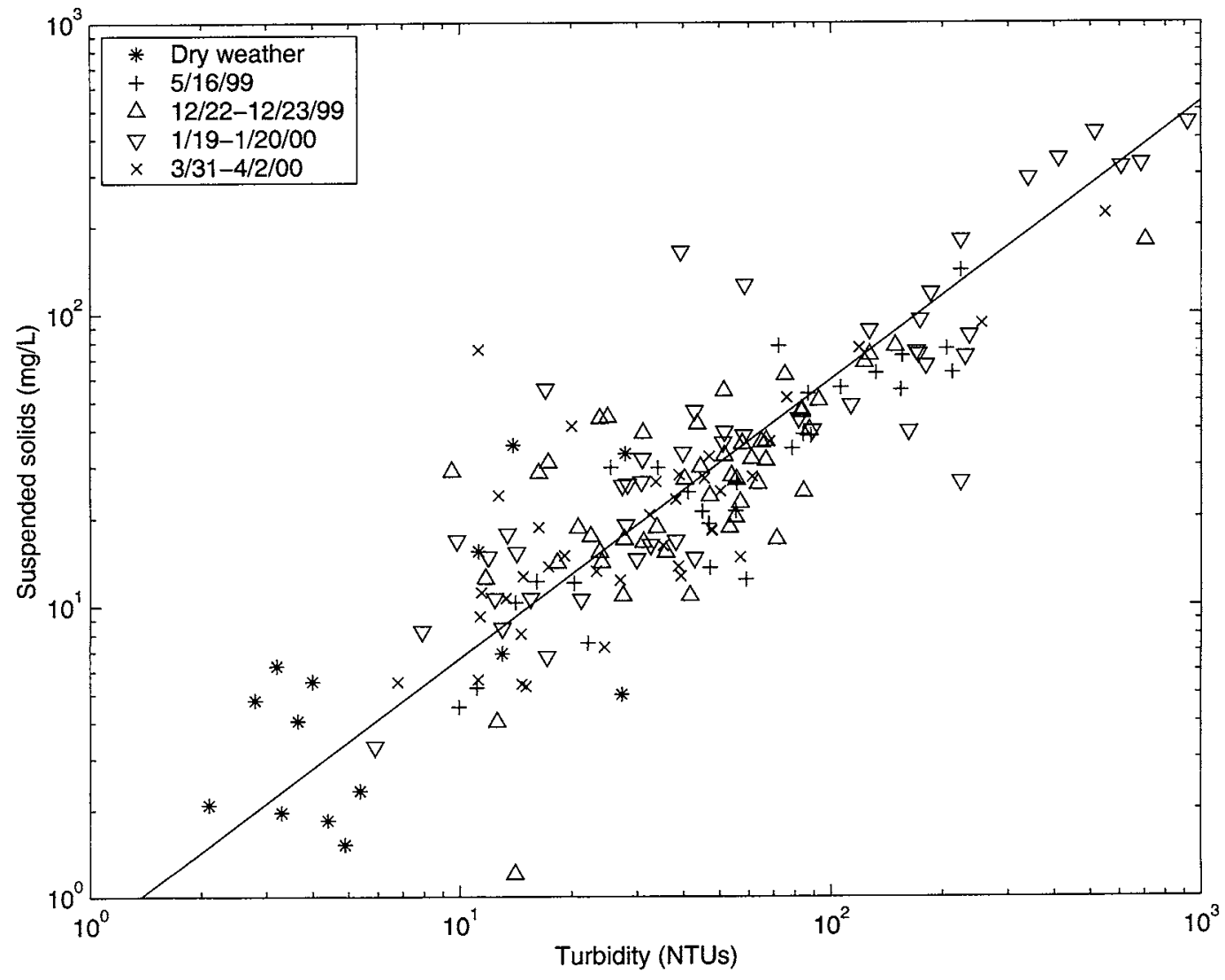

FIGURE 5. Relationship between turbidity and suspended solids for all sampling dates. 
solids is 0.86 , regardless of whether the two variables are the raw data or the log transformed data. The solid line in Figure 5 is a model I least squares regression line and corresponds to the equation

$$
\mathrm{SS}=1.2 \mathrm{~T}^{0.82}
$$

where SS is the suspended solids concentration in $\mathrm{mg}$ /liter and $\mathrm{T}$ is turbidity in NTUs. The standard deviation of the natural $\log$ transformed data about the regression line is 0.57 , meaning that $\mathrm{SS}$ can be predicted to within a factor of $\pm \exp (0.57)=1.77$. Tomlinson and DeCarlo (2001) likewise found a high degree of correlation ( $r=0.82-0.93$ ) between SS and turbidity at two stations in the Mānoa Stream watershed.

\section{DISCUSSION}

Analysis of the elemental composition of the suspended solids in the stream water provides some insight concerning geochemical processes in the watershed. The organic matter in marine microalgae is generally considered to follow a $\mathrm{C}: \mathrm{N}: \mathrm{P}$ stoichiometry of 106:16:1 by atoms (i.e., the classic Redfield ratio [Redfield 1958]). The associated organic matter is generally written as $\left(\mathrm{CH}_{2} \mathrm{O}\right)_{106}\left(\mathrm{NH}_{3}\right)_{16} \mathrm{H}_{3} \mathrm{PO}_{4}$. Such organic matter consists of $0.87 \% \mathrm{P}$ and $6.3 \% \mathrm{~N}$ by weight. Marine macroalgae have an atomic $\mathrm{C}: \mathrm{N}: \mathrm{P}$ of roughly 550:30:1 (Atkinson and Smith 1983). Following similar reasoning, the associated organic matter consists of $0.18 \% \mathrm{P}$ and $2.5 \% \mathrm{~N}$. Finally, terrestrial organic matter has an atomic $C: N: P$ of roughly $822: 9: 1$ (Deevy 1973). Such organic matter consists of $0.125 \% \mathrm{P}$ and $0.50 \% \mathrm{~N}$.

The suspended solids in Waimānalo Stream had a median $\mathrm{P}$ and $\mathrm{N}$ content of $0.11 \% \quad(0.10-0.13 \%)$ and $0.35 \% \quad(0.29-$ $0.42 \%$ ), respectively, where the error bounds are the 95\% confidence limits (Tate and Clelland 1957). The SS therefore resemble terrestrial organic matter and are very different from that of marine microalgae and macroalgae. The fact that the $\mathrm{N}$ content is somewhat lower than that of typical terrestrial organic matter probably reflects the fact that some of the SS is inorganic, most likely minerals resulting from the weathering of basaltic rocks. The fact that the N/P ratio is about 3 by weight rather than the value of 4 associated with "typical" terrestrial organic matter probably reflects the unusually high iron content of Hawaiian soils. Phosphorus is known to bind to ferric iron, and tropical soils are rich in hydrated ferric oxides when compared with soils in other parts of the world. As noted by Martin and Maybeck (1979:189), "The contents of ... Fe ... in the suspended matter of the tropical rivers are the highest [and] the contents of ... Fe ... in temperate and arctic rivers are much lower." It is not surprising that there is a high degree of correlation between the concentration of iron and phosphorus in river-suspended particulates.

Nitrate accounted for the vast majority of DIN in the stream. The median nitrate/DIN ratio was $0.94(0.92-0.95)$. This is not a surprising result in an oxidizing environment. The median DIN/phosphate ratio was 17 (14-22) by weight. This figure is not inconsistent with results reported from other fluvial systems. For example, the N:P ratio by weight in the Cedar River, the principal tributary to Lake Washington near Seattle, is about 18 (W. T. Edmondson, pers. comm.).

Dissolved $\mathrm{N}$ and $\mathrm{P}$ account for most of the $\mathrm{N}$ and $\mathrm{P}$ in the stream water. The median TDN/TN ratio was $0.94(0.93-0.96)$, and the median TDP/TP ratio was $0.78(0.75-0.80)$. These percentages are unusually high for a fluvial system. For example, Martin and Maybeck (1979) stated that over $90 \%$ of the $\mathrm{P}$ transported by rivers to the ocean is in the form of particulate P. This is certainly not the case in Waimānalo Stream. Several factors may contribute to this unusual behavior. First, the stream is polluted with inorganic $N$ and $P$. The most likely sources are animal waste, cesspool seepage, and fertilizer. Regardless of the primary source, the fact that the highest nitrate concentrations were recorded during base flow at station 16 implicates groundwater seepage rather than overland runoff as the mechanism by which nitrate is introduced into the lower portion of Kahawai Stream. 
The other element of the explanation is the fact that the stream channel has been greatly modified in the name of flood control. In particular, riparian trees have been cut down because they were perceived as a potential cause of flooding in the event that large branches or whole trees fell into the channel at an inopportune time and blocked a culvert. The result of the clearing of riparian trees has been the elimination of the shade provided by those trees. The channel itself now receives much more sunlight than formerly. One consequence of the absence of shade has been the proliferation of vegetation within the channel (Figures 3 and 6). The portion of the Kahawai Stream channel for about $0.5 \mathrm{~km}$ below station 18 , for example, is completely overgrown with California grass, wild sugarcane, and other vegetation. It is virtually impenetrable (Figure 6). Some reaches of the stream more closely resemble wetlands than streams, and the vegetation in the channels becomes an effective sediment trap. The channels thus accumulate both vegetation and sediment during base flow and moderate rains. In the event of a large rain, the restriction to flow caused by this accumulation of sediment and vegetation poses a serious threat from the standpoint of flooding. The elimination of the shade provided by riparian trees has thus created a far more dangerous situation with respect to flooding than was the case before the engineering modifications.

DIN accounts for a median of $80 \%$ (76$86 \%)$ of the TDN in the stream. Phosphate, on the other hand, accounts for a median of only $56 \%(51-61 \%)$ of the TDP. The lower contribution of phosphate to the TDP pool probably reflects the aforementioned tendency of phosphate to bind to ferric iron and in this way be removed from the dissolved pool. What is unusual about Waimannalo Stream is the fact that apparently little of the iron-bound phosphate is appearing in the suspended particulate phase, but instead is

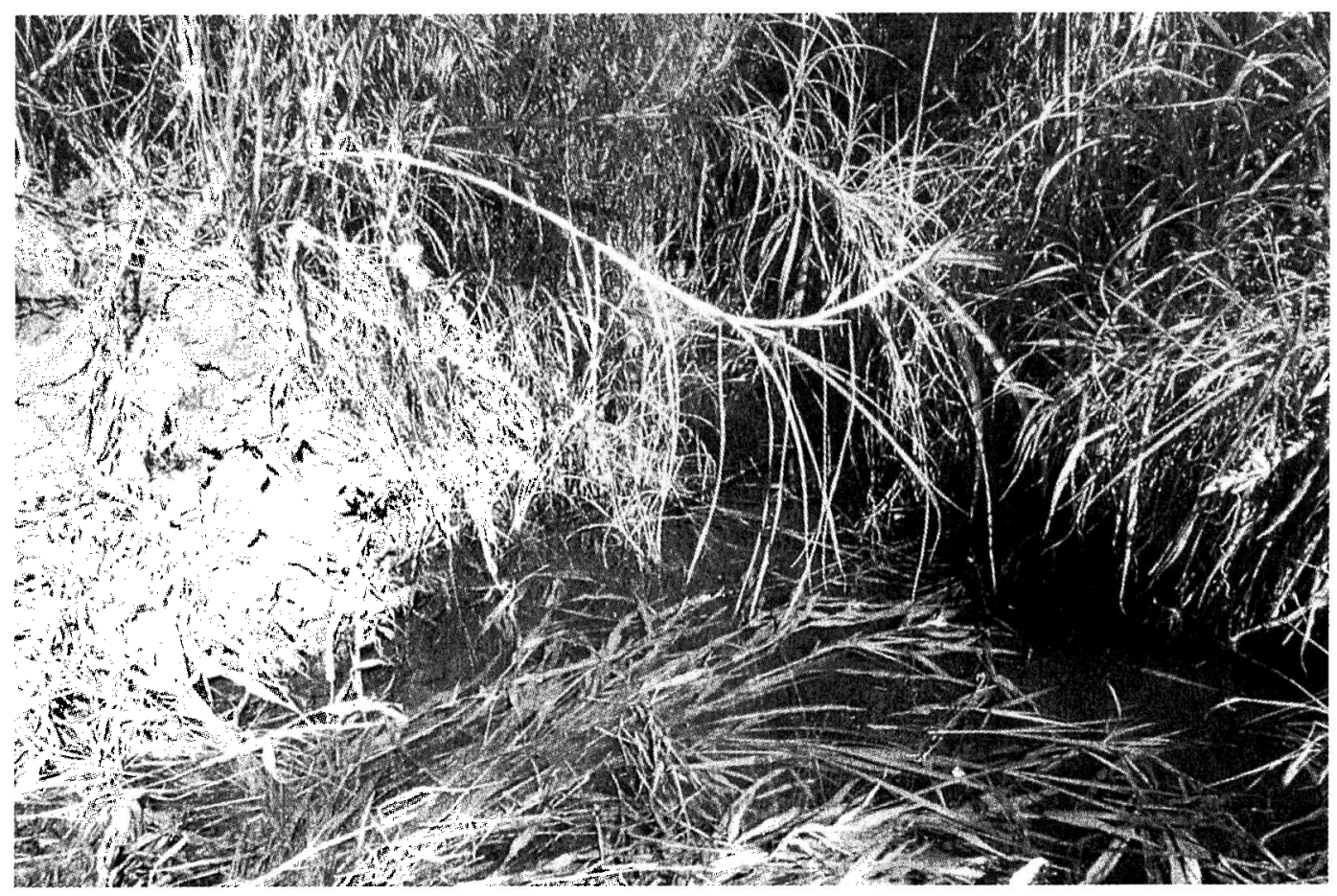

FigURE 6. Vegetation choking Kahawai Stream about $0.5 \mathrm{~km}$ below station 18 . 
being trapped in the sediments at the bottom of the channel because of the wetland nature of many reaches of the stream.

Silicate concentrations are a sensitive indicator of groundwater in the Hawaiian Islands because of the tendency of percolating groundwater to leach silicate from basaltic soils and rocks. The average silicate-Si concentration in windward O'ahu wells is $12 \pm 5$ mg liter ${ }^{-1}$ (Takasaki et al. 1969). The median silicate- $\mathrm{Si}$ concentration measured in this study was $8.8 \mathrm{mg} \mathrm{liter}{ }^{-1}$ (8.1-9.1 $\left.\mathrm{mg} \mathrm{liter}{ }^{-1}\right)$. This compares with silicate-Si concentrations in the offshore ocean that average about 0.03-0.06 mg liter ${ }^{-1}$ (Laws et al. 1999). A notable exception to the high silicate concentrations in Waimanalo Stream was station 7 , where the median silicate-Si concentration was $2.1 \mathrm{mg} \operatorname{liter}^{-1}\left(0.8-2.6 \mathrm{mg} \mathrm{liter} \mathrm{r}^{-1}\right)$. This reflects the fact that the runoff at station 7 is primarily water that has come more or less directly from Mahikū Place (i.e., it has not had a chance to interact with basaltic soils and rocks). Silicate-Si concentrations measured during 26 March 1999, 10 April 1999 (base flow), and 16 May 1999 were distinctly lower (median $=2 \mathrm{mg}$ liter $^{-1}$ ) than during later sampling. The explanation seems to be that the months preceding 16 May 1999 were very dry, and flow in the stream very sluggish. The slow flow may have given diatoms a chance to take up much of the silicate. To check this hypothesis, we reran the silicate analyses for those dates on whole water samples rather than on filtrates. The concentrations measured in this way were two to three times higher than the concentrations measured on the filtrates. Although the standard silicate assay is not considered to be a reliable way to measure particulate silica, it is a simple matter to show that the reagents used in the assay rapidly leach silicate from a glass vial. It appears that during March-May 1999 much of the silicon in the stream was in the particulate rather than dissolved state.

Because factors other than the concentration of suspended solids (e.g., the presence of dissolved substances such as humic acids) can influence the transmission of light in water, there is no reason to believe that the relationship shown in Figure 5 would apply to a
TABLE 4

Annual Fluxes of Water, Nutrients, and SS at Stations 3 and 16 during Base Flow, Rain, and Postrain Periods

\begin{tabular}{lll}
\hline Parameter & Station 3 & Station 16 \\
\hline Water $\left(\mathrm{m}^{3}\right)$ & & \\
$\quad$ Base & $4.84 \times 10^{6}$ & $4.84 \times 10^{6}$ \\
Rain & $1.82 \times 10^{5}$ & $1.82 \times 10^{5}$ \\
$\quad$ Postrain & $1.82 \times 10^{5}$ & $1.82 \times 10^{5}$ \\
Nitrate N (tonnes) & & \\
$\quad$ Base & 1.9 & 34.4 \\
Rain & 0.24 & 0.0 \\
$\quad$ Postrain & 0.34 & 0.17 \\
Total N (tonnes) & & \\
Base & 3.2 & 32.9 \\
Rain & 0.33 & 0.27 \\
$\quad$ Postrain & 0.44 & 0.42 \\
Total P (tonnes) & & \\
Base & 0.15 & 0.20 \\
Rain & 0.046 & 0.073 \\
$\quad$ Postrain & 0.041 & 0.076 \\
SS (tonnes) & & \\
Base & 21.3 & 75.1 \\
Rain & 21.2 & 21.5 \\
Postrain & 11.8 & 14.1 \\
\hline
\end{tabular}

broad range of water types. Nevertheless, it is possible that equation 1 may give a good description of the relationship between turbidity and suspended solids for many Hawaiian streams.

Annual fluxes of water, nutrients, and suspended solids at stations 3 and 16 are shown in Table 4. For purposes of making these estimates, separate calculations were made for base flow and for rain and postrain conditions. Our estimates of water discharge during wet weather sampling at stations 3 and 16 gave very similar values, 410 and 418 liters $\mathrm{sec}^{-1}$, respectively. The base flow water discharge at these two stations was taken to be 87.5 liters $\mathrm{sec}^{-1}$, which is the mean of independent estimates (70 and 105 liters $\mathrm{sec}^{-1}$ ) made by the Hawai' $i$ Department of Health and by us at the two stations.

To estimate fluxes during rain and postrain periods, we needed an estimate of the duration of rain and postrain events. Figure 7 shows the relationship between rainfall and duration of rainfall based on data from the NWS Waimānalo Hydronet station HI-13. The straight line fit to the data corresponds 


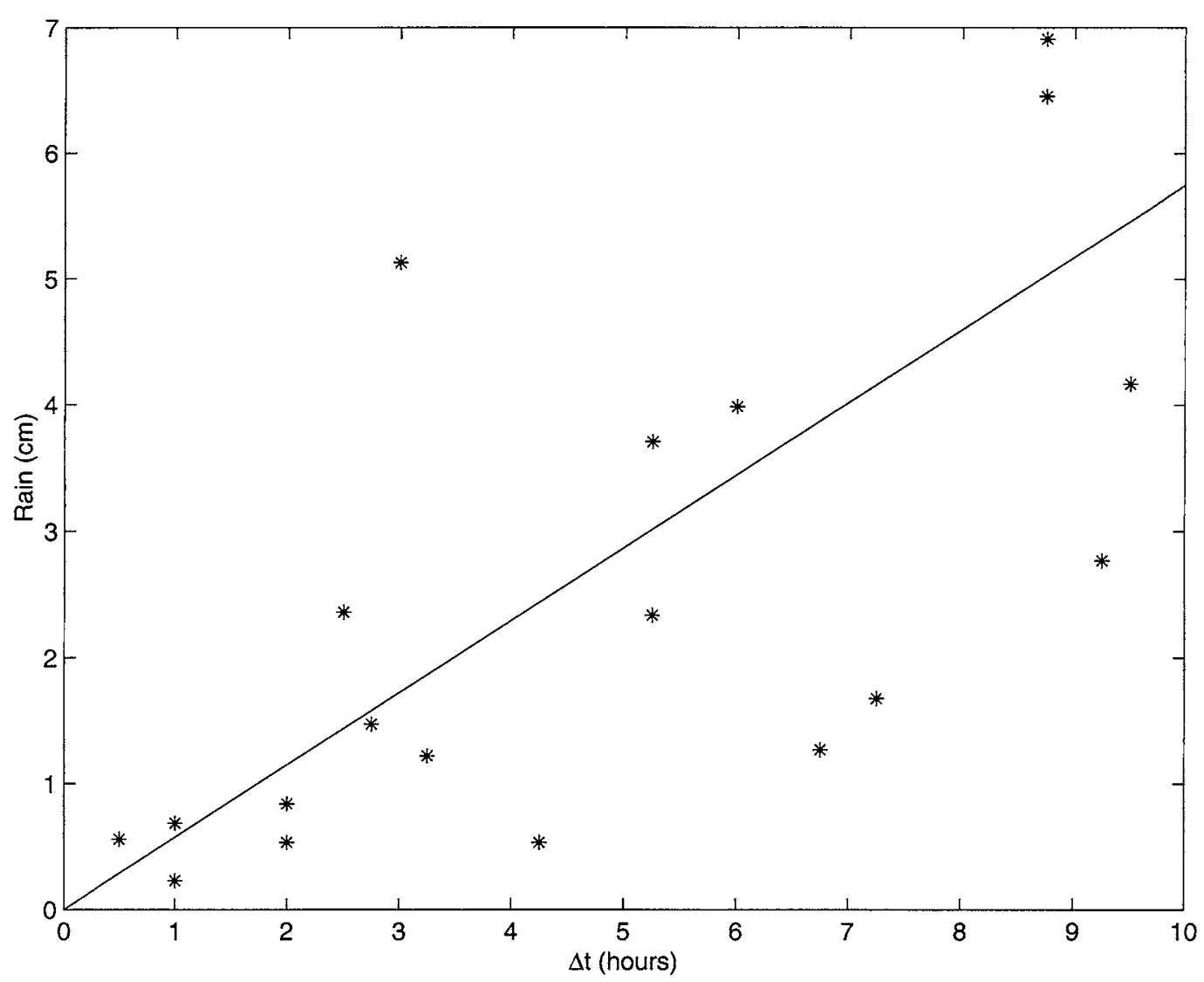

FIGURE 7. Relationship between amount of rainfall and duration of rainfall based on data reported by the National Weather Service Hydronet station HI-13 for selected storms during years 1995, 1996, and 1999.

to the equation $Y=0.574 X$, where $X$ is the duration of the rainfall in hours and $Y$ is the total rainfall in centimeters. Because the NWS station is actually in the Inoaole Stream watershed (Figure 1), we checked the correspondence between the NWS station and a rain gauge operated by the U.S. Geological Survey (USGS) at $21^{\circ} 21^{\prime} 1^{\prime \prime} \mathrm{N}, 157^{\circ} 43^{\prime} 5^{\prime \prime}$ $W$ very near our station 3 . The USGS station does not record data at 15 -min intervals, and during some years data are only available as cumulative rainfall over a period of several months. However, we were able to find blocks of time during 1992, 1993, and 1998 when a comparison of monthly rainfall between the USGS and NWS stations was possible. For the periods October 1992October 1993 and April 1998-September
1998, the correlation coefficient between the monthly rainfall at the two stations was 0.96 . The NWS monthly rainfall exceeded the USGS monthly rainfall by $20 \%$. This result gives some sense of the geographical variability of rainfall within the Waimannalo area. It also suggests that the NWS gauge is a reasonable proxy for rainfall in the Waimānalo Stream watershed.

Average rainfall at the NWS gauge is $112 \mathrm{~cm}$ per year (1985-1999). Based on Figure 7, the duration of the rainfall averages $112 / 0.574=194 \mathrm{hr}$ per year. Estimating the duration of the postrain period is more problematic. Figures 8 and 9 illustrate the variability of the postrunoff period in the cases of the 23 December 1999 and 31 March 2000 storms. On 23 December 1999, turbidities 


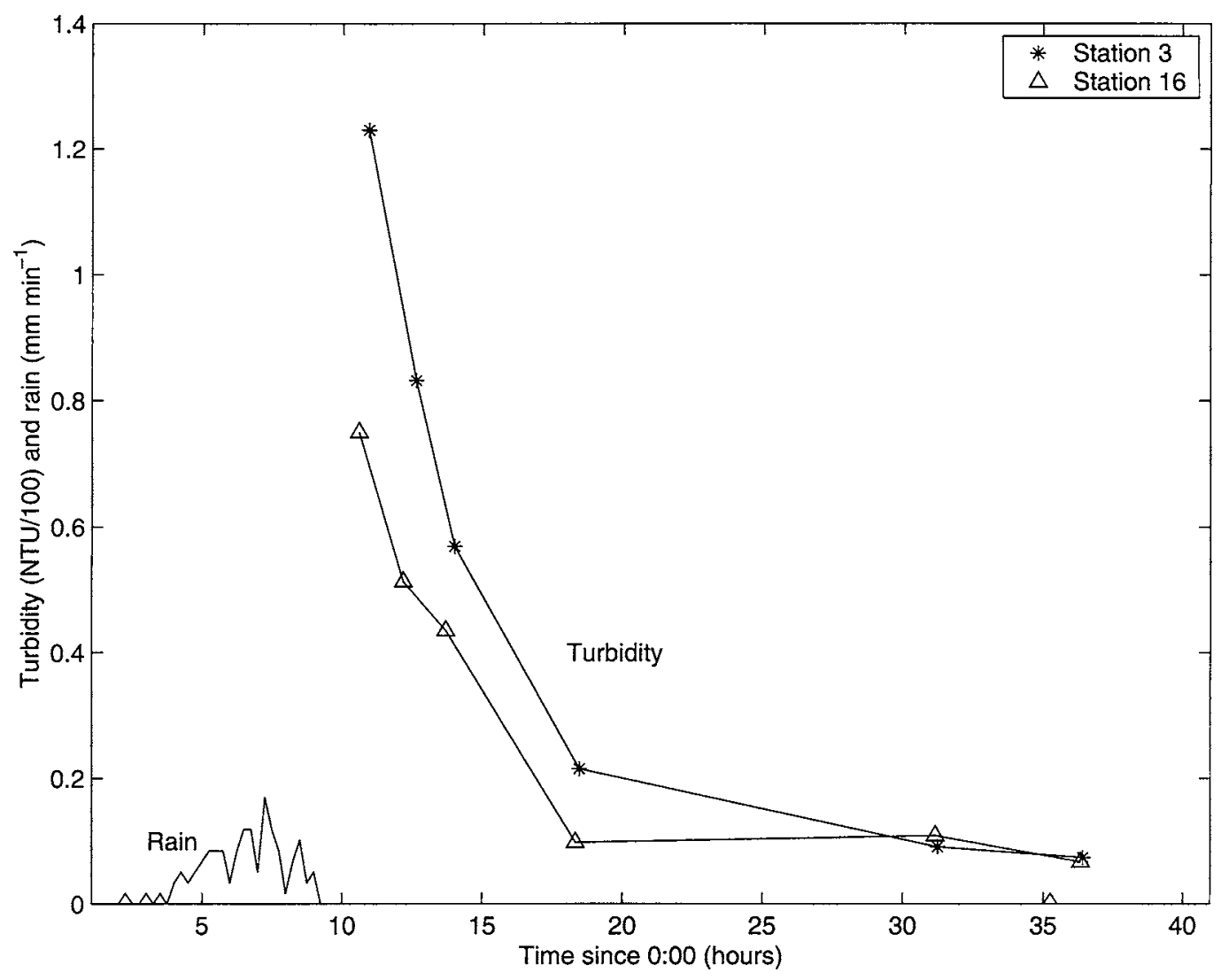

FIGURE 8. Rainfall of 23 December 1999 and response of turbidity at stations 3 and 16 immediately following the rain.

during the period of rainfall were high and did not return to normal for roughly $10 \mathrm{hr}$ after the rainfall stopped. In this case the duration of the rainfall was about $8 \mathrm{hr}$. In the case of the 31 March 2000 storm turbidities began to decline toward the end of the rainfall period and had stabilized within about 6 $\mathrm{hr}$ after the rainfall stopped. In this case the rainfall lasted for about $16 \mathrm{hr}$. In these two examples the duration of the postrainfall period was 1.25 and 0.375 times the duration of the rainfall. In the following calculations we have assumed that the postrainfall period lasts two-thirds as long as the rainfall (i.e., approximately the geometric mean of the above two numbers). The overall flux estimates are rather insensitive to the assumed duration of the postrainfall period.

Because significant correlations exist be- tween stream discharge and nutrient and SS concentrations, estimates of fluxes during the rain and postrain periods must be based on flow-weighted averages. Figures 10-11 illustrate the nature of some of the correlations. Nitrate fluxes at station 16 were negatively correlated with water flow during both rain and postrain conditions (Figure 10). The negative correlation reflects the fact that the nitrate concentration is higher during base flow than under storm runoff conditions. Two examples of the opposite situation are shown in Figure 11. Total P concentrations at station 16 and nitrate concentrations at station 3 were lower during base flow than under storm water runoff conditions. As a result, there was a positive correlation between these concentrations and water flow during postrain conditions. 


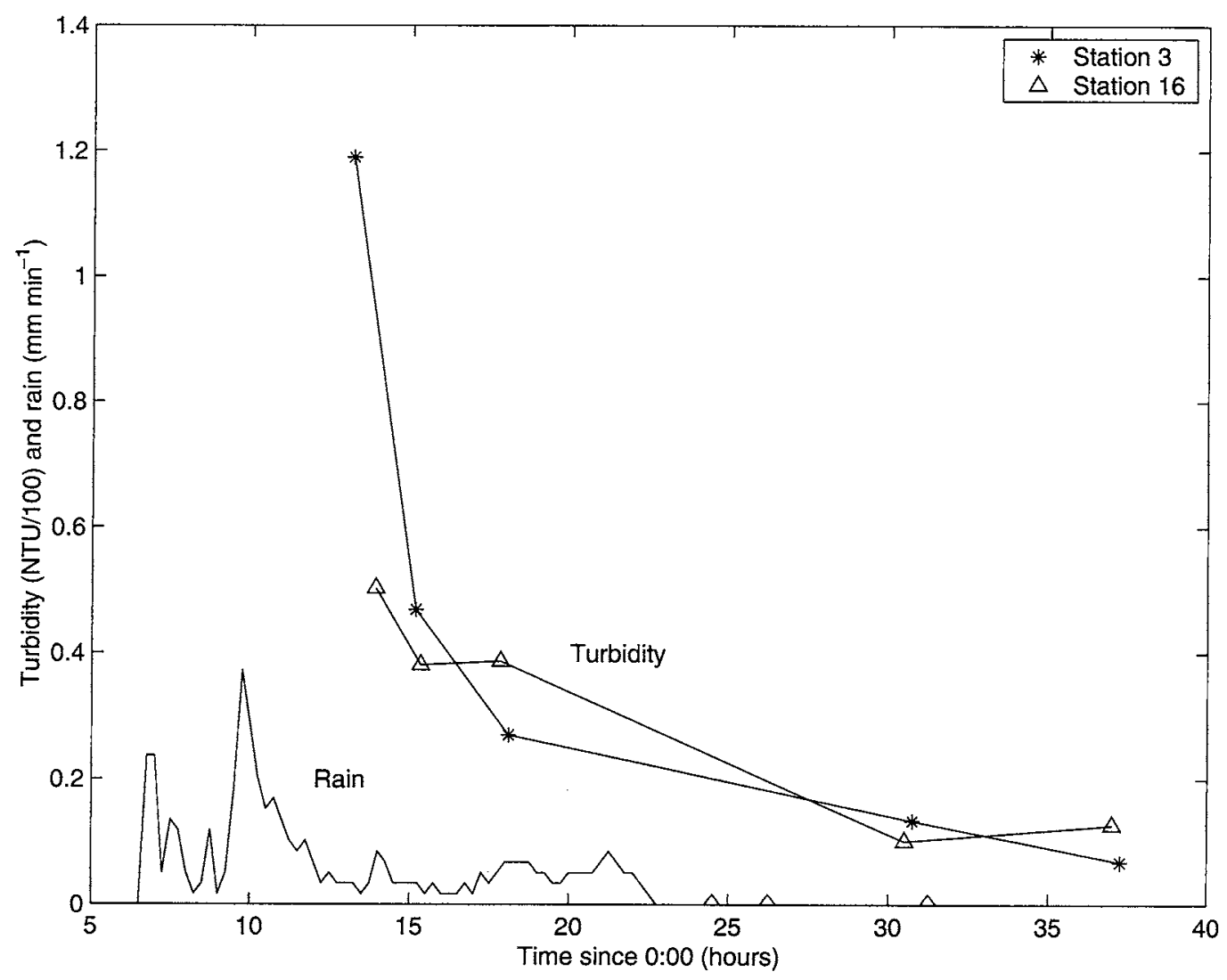

FIGURE 9. Rainfall of 31 March 2000 and response of turbidity at stations 3 and 16 immediately following the rain.

To determine fluxes of nutrients and SS during rain and postrain conditions, the flowweighted concentrations in Table 2 were multiplied by the appropriate water flow rates. The flow during rainfall was assumed to be the same at stations 3 and 16 and equal to 414 liters $\sec ^{-1}$. Rainfall during the study period was anomalously low, and we assumed that this affected base flow. The total rainfall during 1999 was $63.8 \mathrm{~cm}, 57 \%$ of the $1985-$ 1999 average. We assumed the long-term average base flow to be $87.5 / 0.57=153.5$ liters $\mathrm{sec}^{-1}$. The average discharge during the postrain period was accordingly set at $(153.5+414) / 2=284$ liters $\sec ^{-1}$. Using these water discharge rates and the nutrient and SS concentrations in Table 2, we calculated annual fluxes of nutrients and SS. These annual fluxes are shown in Table 5. The fluxes listed for rain and postrain conditions have been corrected for base flow fluxes, which are assumed to occur at all times. In other words, the fluxes listed for rain and postrain conditions are the additional fluxes (above base flow) associated with rain events.

Total runoff from the watershed is estimated to be $1.0 \times 10^{7} \mathrm{~m}^{3} \mathrm{yr}^{-1}$. About $97 \%$ of that figure comes from base flow. For comparison, if the annual rainfall of $112 \mathrm{~cm}$ measured at the NWS gauge is representative of the entire $15.3-\mathrm{km}^{2}$ area of the watershed, then the annual rainfall amounts to $1.7 \times 10^{7} \mathrm{~m}^{3} \mathrm{yr}^{-1}$. The implied runoff ratio is $1.0 / 1.7=0.59$. For comparison, the runoff ratio for the world is about 0.46 (Berner and Berner 1987) and varies from a low of 0.28 for Africa to a high of 0.54 for Asia. There is, however, no reason that the runoff ratio for 


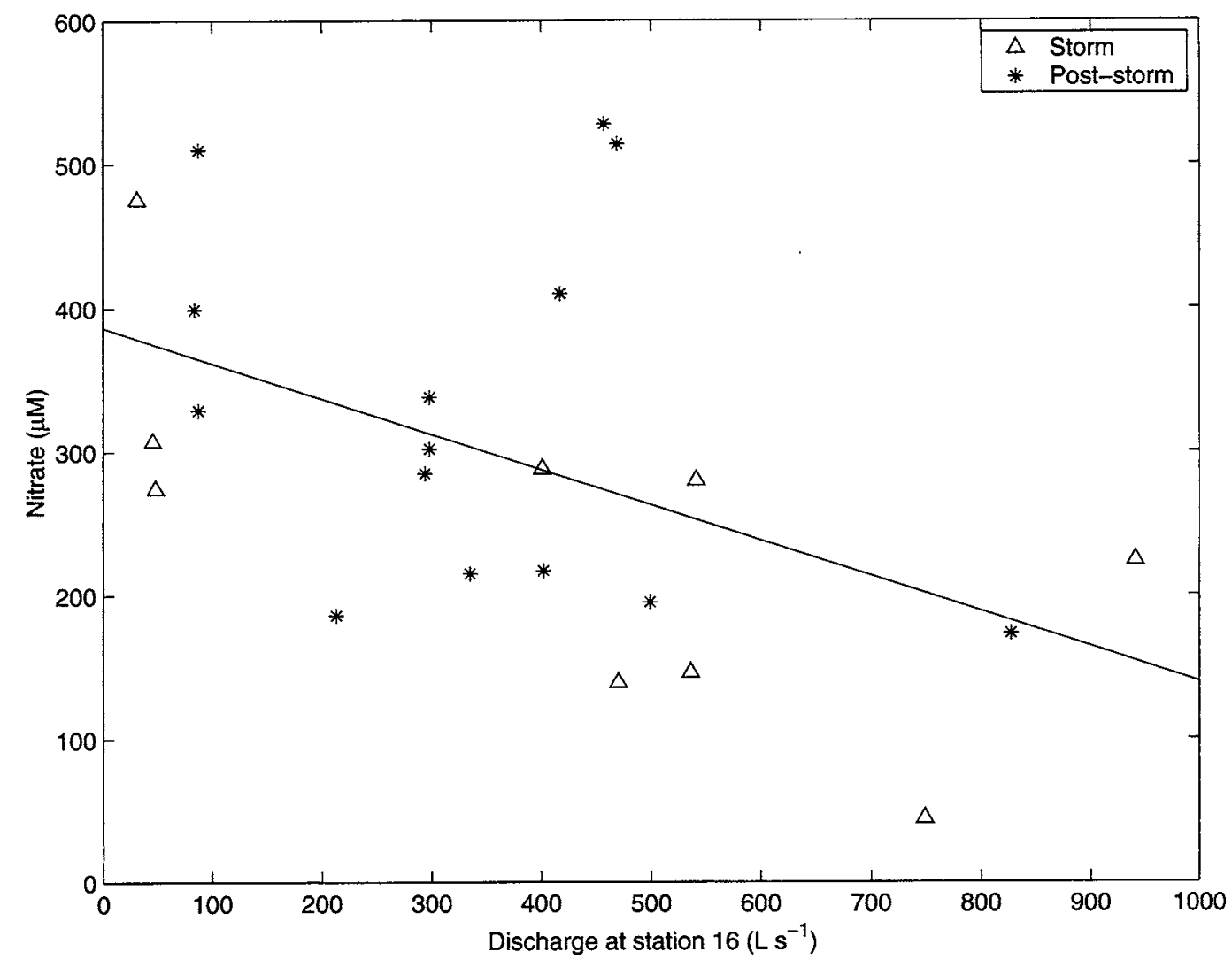

FIGURE 10. Relationship between stream flow and nitrate concentration at station 16 during and shortly after rain events. The correlation coefficient is -0.48 and is significant at $P=0.021$.

one small watershed should lie within the ranges for entire continents. Although rural compared with Honolulu, the Waimannalo watershed includes many impervious surfaces, and portions of both Waimānalo and Kahawai Streams have been hardened. Furthermore, the terrain in the higher-elevation portions of the watershed is very rugged, and rainfall in the mountains is much greater than in the valleys due to orographic effects. On the other hand, roughly half the flow above station 14 is diverted for irrigation. Given these considerations, the calculated runoff ratio of 0.59 seems not unreasonable, but nothing more definitive can be said.

According to Table 5, most of the nitrate $\mathrm{N}$ and total $\mathrm{N}$ fluxes are associated with base flow. This is especially true at station 16 (Kahawai Stream), where the nitrate $\mathrm{N}$ con- centrations are roughly $7 \mathrm{mg}$ liter $^{-1}$ during base flow. However, even at station 3 , base flow accounts for $84 \%$ of the nitrate $\mathrm{N}$ flux and $87 \%$ of the total $\mathrm{N}$ flux. Within the precision of the calculations, runoff during rainfall conditions contributes no additional nitrate $\mathrm{N}$ versus base flow at station 16 . Table 6 compares flow-weighted average concentrations of SS, TN, and TP at stations 3 and 16 with corresponding concentrations estimated for freshwater inputs to five waterquality-limited bodies of water on O'ahu by Freeman (1993) and for average river water (Berner and Berner 1987). The TN concentration of Waimānalo Stream at station 3 is comparable with that of most of the other streams and of average river water. Kahawai Stream at station 16 , however, contains more than seven times as much total $\mathrm{N}$ as the 

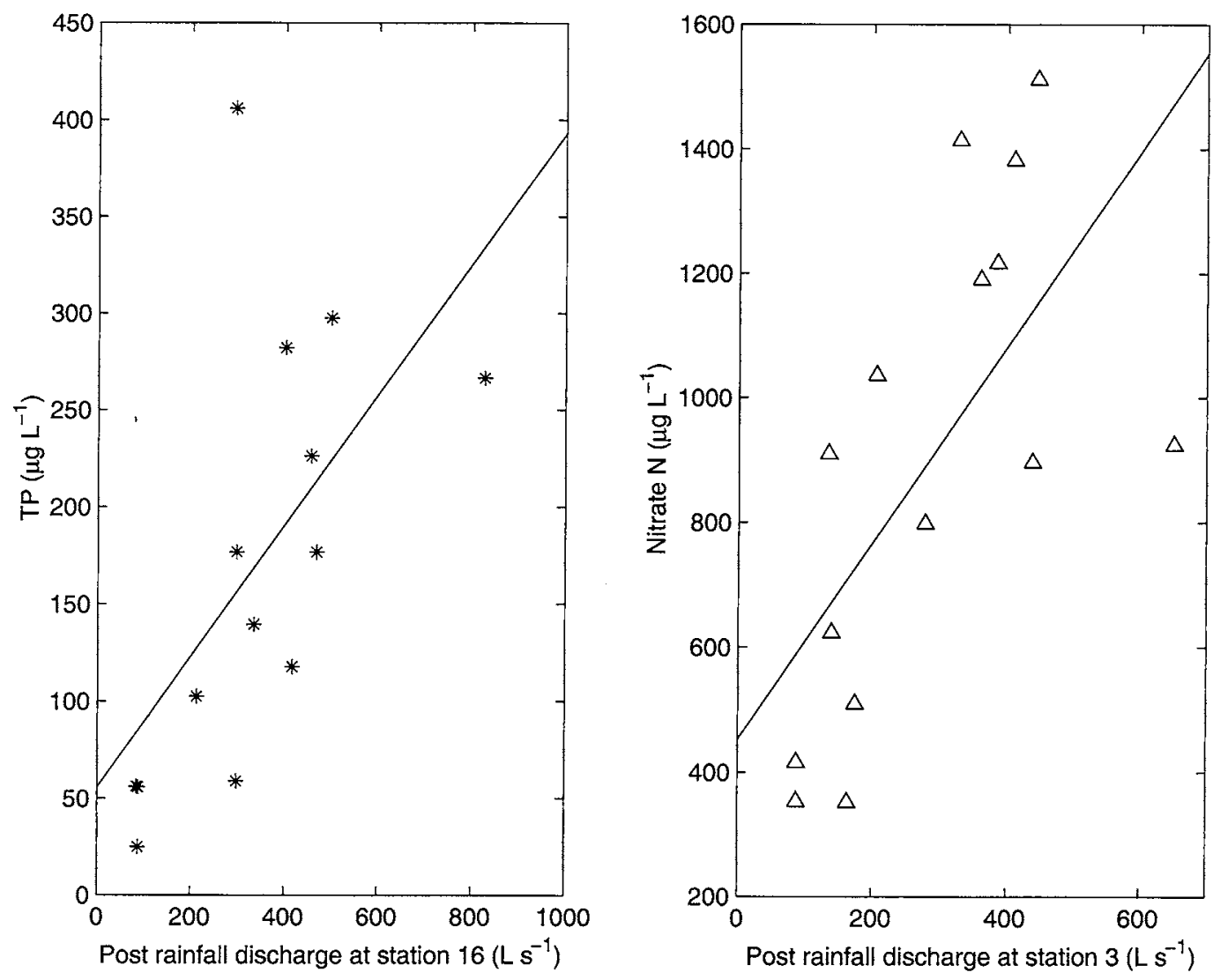

FIGURE 11. Relationship between postrainfall discharge at station 16 and TP concentration (left panel) and postrainfall discharge at station 3 and nitrate concentration (right panel). The correlation coefficients are 0.598 and 0.654 , respectively, and are significant at $P=0.024$ and $P=0.0082$.

O'ahu streams studied by Freeman (1993). The TP concentrations of the latter are only about one-third of the TP in average river water, and the TP concentrations in Waimänalo Stream are lower by an additional factor of 4. According to Berner and Berner (1987), about $90 \%$ of the TP in typical river water is particulate. The low TP concentrations in Waimānalo Stream are directly related to its low suspended sediment load. The SS concentrations in the O'ahu streams summarized by Freeman (1993) are very comparable with the SS in average river water. Waimannalo Stream is clearly anomalous with respect to its transport of suspended sediment. This reflects the engineering modifications that have been made to the stream. During other than torrential rains, Waimānalo Stream functions as a rather effective sediment trap.

Livestock in the watershed produce about 29 tonnes of $\mathrm{N} \mathrm{yr}^{-1}$ and 7 tonnes of $\mathrm{P} \mathrm{yr}^{-1}$ in their waste (see discussion earlier in this article). The former figure is comparable with the flux of TN in the stream (37 tonnes $\mathrm{yr}^{-1}$ [Table 7]). If the $\mathrm{N}$ concentration in Waimannalo Stream equaled the world average of $1.15 \mathrm{~g} \mathrm{~N} \mathrm{~m}^{-3}$, the flux would be $(1.15$ $\left.\mathrm{g} \mathrm{N} \mathrm{m}{ }^{-3}\right)\left(10.1 \times 10^{6} \mathrm{~m}^{3} \mathrm{yr}^{-1}\right)=11.6$ tonnes $\mathrm{yr}^{-1}$. The leaching of $\mathrm{N}$ from animal waste into shallow groundwater and seepage of that groundwater into Waimānalo Stream could therefore account for much of the elevated 
TABLE 5

Annual Fluxes of Water, Nutrients, and SS at Stations 3 and 16 during Base Flow, Rain, and Postrain Periods

\begin{tabular}{llc}
\hline \hline Parameter & Station 3 & Station 16 \\
\hline Water $\left(\mathrm{m}^{3}\right)$ & & \\
Base & $4.84 \times 10^{6}$ & $4.84 \times 10^{6}$ \\
Rain & $1.82 \times 10^{5}$ & $1.82 \times 10^{5}$ \\
Postrain & $6.07 \times 10^{4}$ & $6.07 \times 10^{4}$ \\
Nitrate N (tonnes) & & \\
$\quad$ Base & 1.9 & 34.4 \\
Rain & 0.24 & 0.0 \\
Postrain & 0.11 & 0.06 \\
Total N (tonnes) & & \\
Base & 3.2 & 32.9 \\
Rain & 0.33 & 0.27 \\
Postrain & 0.15 & 0.14 \\
Total P (tonnes) & & 0.20 \\
Base & 0.15 & 0.073 \\
Rain & 0.046 & 0.025 \\
Postrain & 0.014 & 75.1 \\
SS (tonnes) & & 21.5 \\
Base & 21.3 & 4.7 \\
Rain & 21.2 & \\
Postrain & 3.9 & \\
\hline
\end{tabular}

$\mathrm{N}$ load in the stream. The flux of $\mathrm{P}$ in the stream, however, is less than $10 \%$ of the 7 tonnes $\mathrm{P} \mathrm{yr}^{-1}$ that livestock are estimated to produce. The high iron content of Hawaiian soils tends to immobilize any $\mathrm{P}$ in groundwater, and this fact probably accounts for the very high value (131 by weight) of the TN/ TP flux ratio. Cesspool seepage is another possible source of the high nitrate concentrations in the Kahawai tributary. Cesspool pumping information maintained by the City and County of Honolulu indicates that there are at least 150 cesspools in the watershed.

Table 7 gives estimates of the annual fluxes of water, nutrients, and suspended sediment at all stations except 1 and 7 . Stations 1 and 7 were excluded from the analysis because the fluxes at those stations are very small compared with those of the other stations. An interesting aspect of these calculations is that the fluxes of nitrate and TN from the upper portions of the Waimānalo and Kahawai Stream watersheds are very similar, roughly 2-3 tonnes per year (compare stations 8 and 18). This observation underscores the fact that the very large fluxes of nitrate and $\mathrm{TN}$ at station 16 are the result of inputs in the lower portion of the Kahawai Stream watershed between stations 18 and 16. Furthermore, that input is due almost entirely to base flow. Although the twofold difference in SS flux between stations 3 and 16 is less dramatic, it is also attributable to base flow conditions (Table 5).

A caveat to these calculations is the fact that the period of this study and the preceding 2-3 yr were anomalously dry. USGS maintains a crest gauge station (station no. 16249000) immediately downstream from our station 3. During the $35 \mathrm{yr}$ from 1966 to 2000 inclusive, annual peak discharges were recorded 31 times at that station. The peak annual discharges ranged from $5.7 \times 10^{3}$ to $1.3 \times 10^{5}$ liters $\sec ^{-1}(\mathrm{~J}$. Torikai, USGS, pers.

TABLE 6

Flow-Weighted Average Concentrations of SS, TN, and TP in Freshwater Entering Water-Quality-Limited Segments on O'ahu (Freeman 1993), in Average River Water (Berner and Berner 1987), and at Waimānalo Stream Stations 3 and 16

\begin{tabular}{|c|c|c|c|}
\hline Watershed or Station & SS (mg liter ${ }^{-1}$ ) & $\mathrm{TN}\left(\mu \mathrm{g} \mathrm{liter^{-1 }}\right)$ & $\mathrm{TP}\left(\mu \mathrm{g}\right.$ liter $\left.^{-1}\right)$ \\
\hline Ala Wai Canal & 348 & 749 & 304 \\
\hline Honolulu Harbor & 513 & 805 & 145 \\
\hline Ke'ehi Lagoon & 396 & 821 & 168 \\
\hline Pearl Harbor & 449 & 1,325 & 259 \\
\hline Käne'ohe Bay & 204 & 770 & 174 \\
\hline Average river water & 361 & 1,150 & 590 \\
\hline Waimānalo station 3 & 9 & 724 & 41 \\
\hline Waimānalo station 16 & 20 & 6,557 & 59 \\
\hline
\end{tabular}


TABLE 7

Estimated Annual Fluxes of Water, Nutrients, and Sediment at Stations along Waimānalo and Kahawai Streams

\begin{tabular}{lccccc}
\hline \hline Stream & $\begin{array}{c}\text { Water } \\
\left(\mathrm{m}^{3}\right)\end{array}$ & $\begin{array}{c}\text { Nitrate } \\
\text { (tonnes) }\end{array}$ & $\begin{array}{c}\text { TN } \\
\text { (tonnes) }\end{array}$ & $\begin{array}{c}\text { TP } \\
\text { (tonnes) }\end{array}$ & $\begin{array}{c}\text { SS } \\
\text { (tonnes) }\end{array}$ \\
\hline Waimānalo & & & & & \\
Station 3 & $5.2 \times 10^{6}$ & 2.3 & 3.7 & 0.21 & 46.4 \\
Station 8 & $3.5 \times 10^{6}$ & 1.4 & 2.5 & 0.16 & 35.7 \\
Station 14 & $0.8 \times 10^{6}$ & 0.050 & 0.17 & 0.022 & 5.1 \\
Kahawai & & & & & \\
Station 16 & $5.0 \times 10^{6}$ & 34.5 & 33.3 & 0.30 & 101 \\
Station 17 & $0.2 \times 10^{6}$ & 2.3 & 2.4 & 0.023 & 1.5 \\
Station 18 & $1.3 \times 10^{6}$ & 2.2 & 3.0 & 0.06 & 25 \\
Station 23 & $1.0 \times 10^{6}$ & 0.53 & 0.84 & 0.020 & 6.3 \\
Station 24 & $1.0 \times 10^{6}$ & 0.13 & 0.40 & 0.010 & 1.5 \\
\hline
\end{tabular}

comm.). The peak annual discharge was below the limit of detection during only $4 \mathrm{yr}$, 1992 and 1998-2000. During the four largest annual peak discharges, the gauge height was about $2.3 \mathrm{~m}$ higher than the peak gauge height recorded during our study period. The implication is that very large discharges of water occur on a time frame of perhaps 5-7 $\mathrm{yr}$ in this watershed. These large discharges may be sufficient to scour out much of the sediment and nutrients that have accumulated in the stream channel during the intervening low-flow periods. Taking into account these infrequent but very large discharge events would obviously shift the importance of fluxes associated with base flow and storm runoff toward the latter. No such large discharge occurred during our study period. Indeed there was no discharge large enough to even trigger the USGS crest gauge.

In summary, human activities have caused Waimānalo Stream to behave in an aberrant way with respect to its delivery of nutrients and sediment. Under most conditions the stream functions as a rather effective sediment trap. During the period of our study the SS concentration in the stream was only about $4 \%$ that of a typical fluvial system, and PN and $\mathrm{PP}$ accounted for an anomalously low fraction of the TN and TP, respectively, in the stream. Nitrate accounted for most of the $\mathrm{TN}$, and the concentration of nitrate in the Kahawai tributary was many times higher than in other $\mathrm{O}^{\prime}$ ahu streams and average river water. Elevated nitrate concentrations were most apparent in base flow. Leaching of nutrients from animal waste could have accounted for much of the elevated nitrate concentrations. Cesspool seepage may have been a contributory factor.

\section{ACKNOWLEDGMENTS}

This paper is dedicated to the memory of Nancy Glover. We thank two anonymous reviewers for their helpful comments.

\section{Literature Cited}

American Public Health Association. 1998. Standard methods for the examination of water and wastewater. 20th ed. Washington, D.C.

Atkinson, M. J., and S. V. Smith. 1983. $C: N: P$ ratios of benthic marine plants. Limnol. Oceanogr. 28:568-574.

Bartholomew, H., and Associates. 1959. A general plan for Waimanalo Valley prepared for the Commissioner of Public Lands, Honolulu, Hawaici. Available at Hawai' $i$ State Library, Honolulu.

Berner, E. K., and R. A. Berner. 1987. The global water cycle. Prentice-Hall, Englewood Cliffs, New Jersey.

Chesapeake Bay Program. 1999. Chesapeake 2000 Program. http://www.chesapeakebay. net.pubs/shap1299.pdf. 
Deevey, E. S. 1973. Sulphur, nitrogen, and carbon in the biosphere. Pages 182-190 in G. M. Woodwell and E. B. Peacan, eds. Carbon and the biosphere. WSAEC, Washington, D.C.

Freeman, W. 1993. Revised total maximum daily load estimates for six water quality limited segments Island of Oahu, Hawaii. Report prepared for Environmental Planning Office, Hawai'i Department of Health, November. Available at Department of Health, State of Hawai'i, Honolulu.

Harrigan, J., and S. Burr. 2001. Total maximum daily loads estimated for Waimanalo Stream-Island of Oahu, Hawaii. Report prepared for the U.S. Environmental Protection Agency. Available at Department of Health, State of Hawai'i, Honolulu.

Hawai'i Department of Agriculture. 1987. Agricultural land use maps (ALUM). Planning and Development and Soil Conservation Service. 1:24,000, 1978-1980.

Hawai'i Department of Health. 1998. Land use patterns and potential polluted runoff sources in the Waimanalo watershed, Koolaupoko district, Oahu, Hawaii. State of Hawai'i Department of Health Stream Bioassessment Program, Environmental Planning Office, September.

IFC (International Fertilizer Correspondent). 2001. News from the market: World fertilizer use. http://www.ipipotash.org/ifc3/ market.html.

Kihara, M. 2001. Sediment loading model for TMDL development. Ph.D. diss., University of California at Los Angeles.

Laws, E. A., D. Ziemann, and D. Schulman. 1999. Coastal water quality in Hawaii: The importance of buffer zones and dilution. Mar. Environ. Res. 48:1-21.

Martin, J., and M. Maybeck. 1979. Elemental mass-balance of material carried by major world rivers. Mar. Chem. 7:173-206.

Medeiros, C. P. 1998. Waimanalo livestock populations and waste production. Research report prepared for Eugene Dashiell and the Kailua Bay Advisory Council, 1 September. Available at Kailua Bay Advisory Council, Kāne'ohe, Hawai'i.
Miller, M. 1999. Coastal zone '99. http:// bigfoot.wes.army.mil/c820.html.

Peierls, B., N. Caraco, M. Pace, and J. Cole. 1991. Human influence on river nitrogen. Nature (Lond.) 350:386-387.

Pimentel, D., C. Harvey, P. Resosudarmo, K. Sinclair, D. Kurz, M. McNair, S. Crist, L. Shpritz, L. Fitton, R. Saffouri, and R. Blair. 1995. Environmental and economic costs of soil erosion and conservation benefits. Science (Washington, D.C.) 267:1117-1123.

Population Reference Bureau. 1999. World population data sheet. Population Reference Bureau, Washington, D.C.

Redfield, A. C. 1958. The biological control of chemical factors in the environment. Am. Sci. 46:205-222.

Sustainable Resources Group International. 2001. Waimanalo-Inoaole drainage field study, 1999. Prepared for the Environmental Department, Marine Corps Base Hawai'i, Kailua, Hawaici. Available at Marine Corps Base Hawai'i, Kāne'ohe.

Takasaki, K. J., G. T. Hirashima, and E. R. Lubke. 1969. Water resources of Windward Oahu, Hawaii. Geological Survey Water-Supply Paper 1894. U.S. Government Printing Office, Washington, D.C.

Tate, M. W., and R. C. Clelland. 1957. Nonparametric and shortcut statistics. Interstate Publishers, Danville, Illinois.

Tomlinson, M. S., and E. H. DeCarlo. 2001. Investigations of Waimanalo and Kaneohe Streams. Final report to Hawai'i Department of Health. 31 May. Available at Department of Health, State of Hawai' $i$, Honolulu.

U.S. Environmental Protection Agency. 1999a. Protocol for developing sediment TMDLs. EPA 841-B-99-004. Office of Water (4503F), U.S. Environmental Protection Agency, Washington, D.C.

- 1999b. Protocol for developing nutrient TMDLs. EPA 841-B-99-007. Office of Water (4503F), U.S. Environmental Protection Agency, Washington, D.C.

U.S. Geological Survey. 1982. Measurement and computation of streamflow. Vol. 1. Measurement of stage and discharge. 
Geological Survey Water-Supply Paper 2175. U.S. Government Printing Office, Washington, D.C.

Ver, L. M., F. T. Mackenzie, and A. Lerman. 1994. Modeling pre-industrial C-N-P-S biogeochemical cycling in the land-coastal margin system. Chemosphere 29:855-887.

Weber, P. 1993. Abandoned seas: Reversing the decline of the oceans. Worldwatch Pap. 116. 